\title{
Expression of choline and acetylcholine transporters in synovial tissue and cartilage of patients with rheumatoid arthritis and osteoarthritis
}

\author{
Janet Beckmann • Jan Schubert • Hans-Georg Morhenn • \\ Veronika Grau • Reinhard Schnettler • \\ Katrin Susanne Lips
}

Received: 24 March 2014 / Accepted: 15 October 2014 / Published online: 25 November 2014

(C) The Author(s) 2014. This article is published with open access at Springerlink.com

\begin{abstract}
Increasing evidence is showing that the nonneuronal cholinergic system plays an important role in the pathology of rheumatoid arthritis (RA). Choline transport into the cell is the rate-limiting step for the synthesis of acetylcholine (ACh), which can be released directly or in vesicles from the cell. However, in the human joint little is known about choline import or the release of $\mathrm{ACh}$ from the cell. Thus, we analyze the expression of members of the organic cation transporter (OCT), of the newly discovered choline transporter-like (CTL) family and of classical neuronal components such as the high-affinity choline transporter (CHT1) and the vesicular $\mathrm{ACh}$ transporter (VAChT) in the synovium and cartilage of the human hip joint from patients with osteoarthritis (OA) and RA. OCT1, OCT3 and OCTN1 and all members of the CTL family were expressed in synovial and cartilage samples. The expression of CTL1 and CTL2 was localized in synovial macrophages and fibroblasts. CHT1 mRNA expression was detectable only in the synovium, whereas VAChT was completely absent in
\end{abstract}

The work was supported by the LOEWE research focus "Non-neuronal Cholinergic Systems", funded by the HMWK.

Electronic supplementary material The online version of this article (doi:10.1007/s00441-014-2036-0) contains supplementary material, which is available to authorized users.

J. Beckmann $(\bowtie) \cdot J$. Schubert $\cdot$ H.-G. Morhenn $\cdot$ R. Schnettler $\cdot$

K. S. Lips

Laboratory of Experimental Trauma Surgery, Justus-Liebig

University, Schubert Strasse 81, 35392 Giessen, Germany

e-mail: Janet.Beckmann@chiru.med.uni-giessen.de

V. Grau

Laboratory of Experimental Surgery, Justus-Liebig University,

Giessen, German

R. Schnettler

Department of Trauma Surgery Giessen, University Hospital of

Giessen-Marburg, Giessen, German all samples. Therefore, in the human joint, choline transport into the cell and the release of $\mathrm{ACh}$ seems to be mediated mainly by members of the OCT and CTL family. Expression of transporters appears not to be influenced by the pathological state, as no differences have been detected between joints from OA or RA patients. Importantly, however, all necessary components for choline import and the release of non-neuronal $\mathrm{ACh}$ are present in the human joint.

Keywords Rheumatoid arthritis $\cdot$ Non-neuronal cholinergic system - Acetylcholine $\cdot$ Choline transporter-like proteins . Organic cation transporter $\cdot$ Human

\section{Introduction}

Acetylcholine (ACh) is commonly known as a neurotransmitter. Nevertheless, increasing research has recently concentrated on the importance of $\mathrm{ACh}$ as a signaling molecule in nonneuronal cells in which it can play a role in regulating various biological functions (Beckmann and Lips 2013). ACh exerts its functions by acting on muscarinic and nicotinic receptors present on effector cells. The expression of these receptors is, however, not an indication for the existence of a non-neuronal cholinergic system (NNCS) which is characterized by the ability of the cell to produce and release ACh. The synthesis of ACh from choline and acetyl coenzyme A is facilitated by the enzyme choline acetyltransferase (ChAT; Wessler et al. 2003). In some non-neuronal cells, ACh can alternatively be produced by carnitin acetyltransferase (CarAT; Lips et al. 2007; Tucek 1982). The uptake of choline into the cell is one of the essential and rate-limiting factors for the synthesis of ACh. Choline is a positively charged quaternary amine that requires carrier-mediated transport into the cell. The highaffinity choline transporter (CHT1) is the transporter with 
Table 1 Human primer pairs used for qualitative an real-time RT-PCR (CHT high-affinity choline transporter, CTL choline transporter-like, OCTN organic cation transporters novel, $O C T$ organic cation transporter, VAChT vesicular acetylcholine transporter, $\beta M G \beta 2$-microglobulin)

\begin{tabular}{|c|c|c|c|c|}
\hline Gene & Primer sequence & Length (bp) & Annealing temperature $\left({ }^{\circ} \mathrm{C}\right)$ & Accession number \\
\hline CHT1 & $\begin{array}{l}\text { ATCCCAGCCATACTCATT } \\
\text { CAGAAACTGCACCAAGACCA }\end{array}$ & 168 & 59 & NM_021815.2 \\
\hline CTL1 & $\begin{array}{l}\text { GTTCACTTGGAGGCACAGGT } \\
\text { GGCGATGGTAAGAGCAACAC }\end{array}$ & 206 & 62 & ВC049203.1 \\
\hline CTL2 & $\begin{array}{l}\text { AAACCCTTGGCCCGGAGATGCT } \\
\text { GCCGCGCCTCTAGGACTCCAT }\end{array}$ & 160 & 62 & ВС040556.1 \\
\hline CTL3 & $\begin{array}{l}\text { TCCTTGGCCTGTGTATCCTCGCA } \\
\text { ACACCGCAGACAAACAACAATCCCA }\end{array}$ & 130 & 62 & AL540829 \\
\hline CTL4 & $\begin{array}{l}\text { TGCCTACTGGGCCATGACTGCT } \\
\text { ACAAGGTGGGCCGTGGGGTT }\end{array}$ & 138 & 62 & ВC014659 \\
\hline CTL5 & $\begin{array}{l}\text { CTGCTGAAGGAAGGAAGCAAAGCCA } \\
\text { AGGTACCCCCGATGTCGCCAA }\end{array}$ & 138 & 62 & ВC051740 \\
\hline OCTN1 & $\begin{array}{l}\text { CTGTGGAGGAGCTAAATCCCCTGAA } \\
\text { AGGAGCATCCAGAGACAGAGCAA }\end{array}$ & 149 & 59 & ВC028313 \\
\hline OCT1 & $\begin{array}{l}\text { GACGCCGAGAACCTTGGG } \\
\text { GGGTAGGCAAGTATGAGG }\end{array}$ & 198 & 55 & NM_003057 \\
\hline OCT2 & $\begin{array}{l}\text { TCGTCCATCGTCACCGAGT } \\
\text { TATCTCCGCCCAACAAATC }\end{array}$ & 302 & 59 & NM_003058 \\
\hline ОСТ3 & $\begin{array}{l}\text { GGAGTTTCGCTCTGTTCAGG } \\
\text { GGAATGTGGACTGCCAAGTT }\end{array}$ & 216 & 55 & NM_021977 \\
\hline VAChT & $\begin{array}{l}\text { TACCCTACGGAGAGCGAAGA } \\
\text { CTGTAGAGGCGAACATGACG }\end{array}$ & 157 & 59 & U10554 \\
\hline$\beta \mathrm{MG}$ & $\begin{array}{l}\text { TCTCTCTTTCTGGCCTTGGAG } \\
\text { CAACTTCAATGTCGGATGGA }\end{array}$ & 134 & 59 & NM_004048 \\
\hline
\end{tabular}

the highest affinity for choline and is $\mathrm{Na}^{+}$- and $\mathrm{Cl}^{-}$-dependent. CHT1 is required for choline uptake in neuronal cells and without CHT1, neurons are unable to synthesize ACh (Ferguson et al. 2004). Even though some non-neuronal cells have been shown to express CHT1 (Lips et al. 2003; Pfeil et al. 2003), many non-neuronal cells that synthesize ACh do not express this transporter, indicating that other mechanisms of choline transport must exist. Notably, members of $\mathrm{Na}^{+}$independent polyspecific organic cation transporters (OCT13 ) of the solute carrier protein (SLC) 22 family have been shown to have low affinity for choline (Koepsell 2004).
Choline can be taken up by OCT1 and by OCT2. OCT3, however seems not to be able to recognize choline as a substrate (Busch et al. 1996; Sweet et al. 2001). Recently, the family of choline transporter-like (CTL) proteins has been identified as $\mathrm{Na}^{+}$-independent transporters with intermediate affinity for choline (O'Regan et al. 2000). To date, five members of this transporter family, CTL1-5, have been identified (Traiffort et al. 2005) but have not been extensively studied as yet. The best-characterized member CTL1 shows ubiquitous expression (Michel and Bakovic 2012) and CTL1-dependent choline transport has been described in many different cell

Table 2 Antibodies and blocking peptides used for single-stain immunohistochemistry ( $C H T$ high-affinity choline transporter, $C T L$ choline transporterlike, $O C T$ organic cation transporter)

\begin{tabular}{|c|c|}
\hline Primary antibody & Peptide \\
\hline Mouse anti-human CTL1 (1:100); Abgent (\#AT3924a) & CTL1 blocking peptide (200 $\mu \mathrm{g} / \mathrm{ml})$; Abgent (\#BP14061c) \\
\hline Mouse anti-human CTL2 (1:400); Acris (\#AM21005PU-N) & CTL2 recombinant protein $(200 \mu \mathrm{g} / \mathrm{ml})$; Acris (\#H00057153-Q01) \\
\hline Rabbit anti-rat CHT1 (1:10,000; Lips et al. 2002; $92 \%$ homology to human) & Rat CHT1 peptide (200 $\mu \mathrm{g} / \mathrm{ml}$; Lips et al. 2002) \\
\hline $\begin{array}{l}\text { Rabbit anti-human OCT1 (1:150); Aviva Systems } \\
\text { Biology (\#ARP41516_T100) }\end{array}$ & $\begin{array}{l}\text { OCT1 blocking peptide }(200 \mu \mathrm{g} / \mathrm{ml}) \text {; Aviva } \\
\text { Systems Biology (\#AAP41516) }\end{array}$ \\
\hline $\begin{array}{l}\text { Rabbit anti-rat OCT3 (1:300); Alpha Diagnostics } \\
\quad \text { (\#OCT31-A; } 94 \% \text { homology to human) }\end{array}$ & OCT3 blocking peptide $(200 \mu \mathrm{g} / \mathrm{ml})$; Alpha Diagnostics (\#OCT31-P) \\
\hline
\end{tabular}


Table 3 Antibodies used for double-stain immunohistochemistry with two mouse monoclonal primary antibodies (CTL choline transporter-like)

\begin{tabular}{ll}
\hline First primary antibody (blue) & Second primary antibody (brown) \\
\hline Mouse anti-human CD68 (Clone PGM1; 1:200); DAKO & Mouse anti-human CTL1 (1:100) \\
Mouse anti-human CD163 (Clone EDHu-1; 1:200); AbD Serotec (\#MCA1853T) & Mouse anti-human CTL1 (1:100) \\
$\begin{array}{l}\text { Mouse anti-human prolyl-4-hydroxylase- } \beta \text { (Clone 3-2B12; 1:80); } \\
\quad \text { Acris (\#AF0910-1) }\end{array}$ & Mouse anti-human CTL1 (1:100) \\
Mouse anti-human CTL2 (1:200) & Mouse anti-human CD68 (Clone PGM1; 1:300) \\
Mouse anti-human CTL2 (1:200) & Mouse anti-human CD163 (1:300) \\
Mouse anti-human CTL2 (1:200) & Mouse anti-human prolyl-4-hydroxylase- $\beta$ (Clone 3-2B12; 1:80) \\
\hline
\end{tabular}

types, including non-neuronal (Uchida et al. 2009; Yabuki et al. 2009) and neuronal (Machova et al. 2009; Yamada et al. 2011) cells. Interestingly, CTL1 expression seems to be regulated by extracellular choline availability, as choline deficiency can lead to the down-regulation of this transporter (Michel and Bakovic 2009). CTL2 has been shown to be expressed in several tissues such as muscle, kidney, heart, lung and the inner ear (Traiffort et al. 2013). Its role in choline transport has recently been described for heterologously expressed human CTL2 in Xenopus laevis oocytes (Kommareddi et al. 2010) and in lung adenocarcinoma cells (Nakamura et al. 2010). Expression of CTL3 has been found in kidney, ileum, and colon, while CTL4 is predominantly present in intestine, stomach, and kidney (Traiffort et al. 2005). Little is known about expression of CTL5, which has been found to low extend in the brain and in the spinal cord (Traiffort et al. 2013) and in small cell lung carcinoma cells, where it has been shown to be involved in choline transport (Song et al. 2013). Most interestingly, in cancer cells CTL4 does not only facilitate choline uptake but further seems to be specifically linked to ACh synthesis and secretion, as knock down of CTL4 resulted in a significant reduction of ACh (Song et al. 2013). The efficient release of ACh is another important factor characterizing a functional NNCS. In neuronal cells, the vesicular ACh transporter (VAChT) is required for ACh secretion. VAChT mediates the storage of ACh vesicles from which $\mathrm{ACh}$ is quantally released (Erickson

Table 4 Antibodies used for double-stain immunohistochemistry with mouse and rabbit primary antibodies (CarAT carnitin acetyltransferase, CTL choline transporter-like)

\begin{tabular}{|c|c|}
\hline Primary rabbit antibody (blue) & $\begin{array}{l}\text { Primary mouse } \\
\text { antibody (brown) }\end{array}$ \\
\hline $\begin{array}{l}\text { Rabbit anti-human CarAT (1:100); LSBio (\#LS- } \\
\text { C167021/52635); preabsorption control with } \\
\text { blocking peptide (LS-E8292/40 - LSBio) }\end{array}$ & $\begin{array}{l}\text { Mouse anti-human } \\
\text { CTL1 (1:100) }\end{array}$ \\
\hline $\begin{array}{l}\text { Rabbit anti-human CarAT (1:100); LSBio (\#LS- } \\
\text { C167021/52635); preabsorption control with } \\
\text { blocking peptide (LS-E8292/40 - LSBio) }\end{array}$ & $\begin{array}{l}\text { Mouse anti-human } \\
\text { CTL2 (1:400) }\end{array}$ \\
\hline $\begin{array}{l}\text { Rabbit anti-human von Willebrand factor } \\
(1: 10,000) \text {; Merck Millipore (\#AB736) }\end{array}$ & $\begin{array}{l}\text { Mouse anti-human } \\
\text { CTL2 }(1: 400)\end{array}$ \\
\hline
\end{tabular}
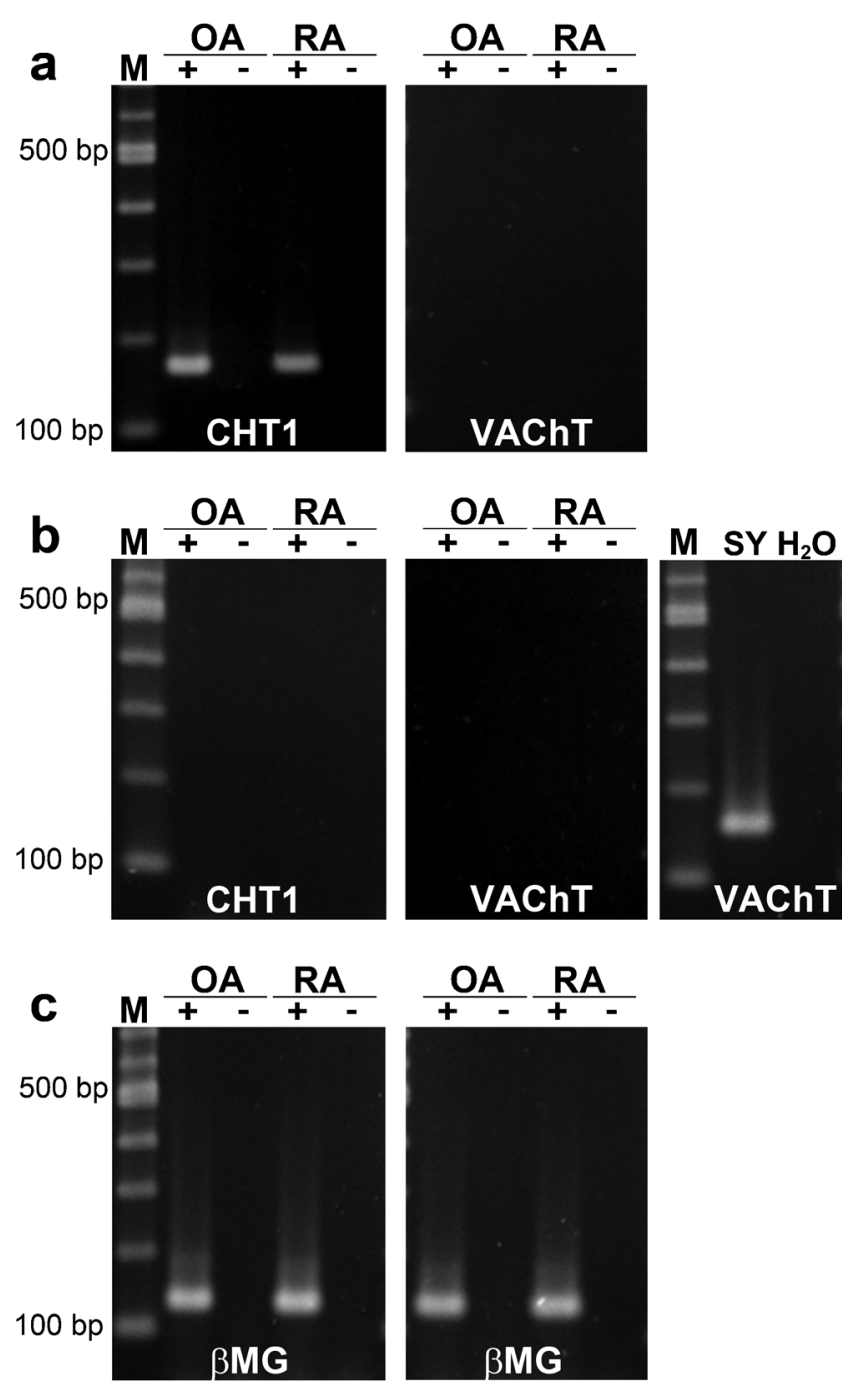

Fig. 1 mRNA expression of the classical neuronal transporters CHT1 (high-affinity choline transporter 1) and VAChT (vesicular acetylcholine transporter) in the human joint. a, b RT-PCR for CHTl and VAChT mRNA in synovial (a) and cartilage (b) samples from the hip of osteoarthritis $(O A)$ and rheumatoid arthritis $(R A)$ patients (lanes $M 100 \mathrm{bp}$ ladder, lanes $+\mathrm{RT}+[$ reverse transcription with template], lanes $-\mathrm{RT}-$ [RT without template]). SH-SY5Y (Sy) was used as a positive control for $V A C h T$ expression and water $\left(\mathrm{H}_{2} \mathrm{O}\right)$ was employed instead of cDNA as a negative control. c Representative RT-PCR for $\beta 2$-microglobulin $(\beta M G)$ in samples of synovia (left) and cartilage (right) from the hip of $\mathrm{OA}$ and RA patients 
et al. 1994). VAChT expression and vesicular storage and release have only been reported in some non-neuronal cells such as pancreatic $\alpha$-cells (Rodriguez-Diaz et al. 2011), endothelial cells (Kirkpatrick et al. 2001) and cardiomyocytes (Rana et al. 2010). In most non-neuronal cholinergic cells, $\mathrm{ACh}$ is not stored in vesicles but is directly released via transporters. Of the family of organic cation transporters, OCT1 and OCT2 have been revealed to be able to translocate ACh out of the cell in the human airway (Lips et al. 2005), whereas in the placenta, ACh release is mediated by OCT1 and OCT3 (Wessler et al. 2001). Recently, a new family of OCTs, the organic cation transporters novel (OCTN), has been identified in higher organisms (Eraly et al. 2004) and the family member OCTN1 has been demonstrated to catalyze the transport of ACh (Pochini et al. 2012). Further, the mediatophore, a protein of $220 \mathrm{kDa}$ consisting of $15-\mathrm{kDa}$ proteolipid subunits of the vacuolar $\mathrm{H}^{+}$-ATPase, is thought to be involved in ACh exocytosis (Fujii et al. 2012; Israel and Dunant 1998).

Evidence is increasing that the cholinergic system can play an important role in the pathology of rheumatoid arthritis (RA; Pan et al. 2010). Depending on mode, time-point and immune status, the administration of nicotine has been shown to ameliorate experimental arthritis (Lindblad et al. 2009; van Maanen et al. 2009; Yu et al. 2011). However, the role of the $\alpha 7$ nicotinic receptor, which is known to function in the antiinflammatory cholinergic pathway (Tracey 2009), is still being discussed controversially in this regard (van Maanen et al. 2010; Westman et al. 2010).

In general, little is known about the NNCS in the human joint. Grimsholm et al. in 2008 were able to show the expression of ChAT and the $\alpha 7$ nicotinic receptor in synovial tissue of the human knee joint in patients with RA and osteoarthritis (OA). A study of our own group confirmed the expression of $\alpha 7$ nicotinic receptor, other subunits of nicotinic receptors and various isotypes of muscarinic receptors (Schubert et al. 2012) even though we could not clearly determine the mRNA expression of ChAT, the ACh-synthsizing enzyme CarAT was clearly detectable. With regard to choline and ACh transporters, we could further identify the expression of OCT1 and OCT3 in the synovial tissue of the knee joints of RA and OA patients.

In the present study, we analyze the expression of various choline and ACh transporters, with special regard to the newly discovered choline transporter-like proteins, in the human joint. Even less information is available on the expression of the NNCS in cartilage. Thus, in addition to the synovial tissue, we also analyze samples of cartilage for choline and ACh transporter expression.

\section{Materials and methods}

Patients and samples

Synovial tissue and cartilage was obtained from RA and OA patients at the time of hip joint replacement. All patients fulfilled the criteria of the American College of Rheumatology Classification for RA (Arnett et al. 1988) and OA (Altman et al. 1986). Written informed consent was obtained from all participants. The study was performed according to the Declaration of Helsinki and was approved by the local ethical committee.
Fig. 2 Expression of organic cation transporter mRNA in the human joint. a, b RT-PCR for organic cation transporter 1-3 (OCT1-3) and organic cation transporter novel (OCTN1) mRNA in synovia (a) and cartilage (b) from the hip of OA and RA patients (lanes M $100 \mathrm{bp}$ ladder, lanes + RT+, lanes - RT-). $\mathrm{CaCo}-2$ cells $(C C)$ were used as a positive control for $O C T 2 \mathrm{mRNA}$ expression and water $\left(\mathrm{H}_{2} \mathrm{O}\right)$ was employed instead of cDNA template as a negative control
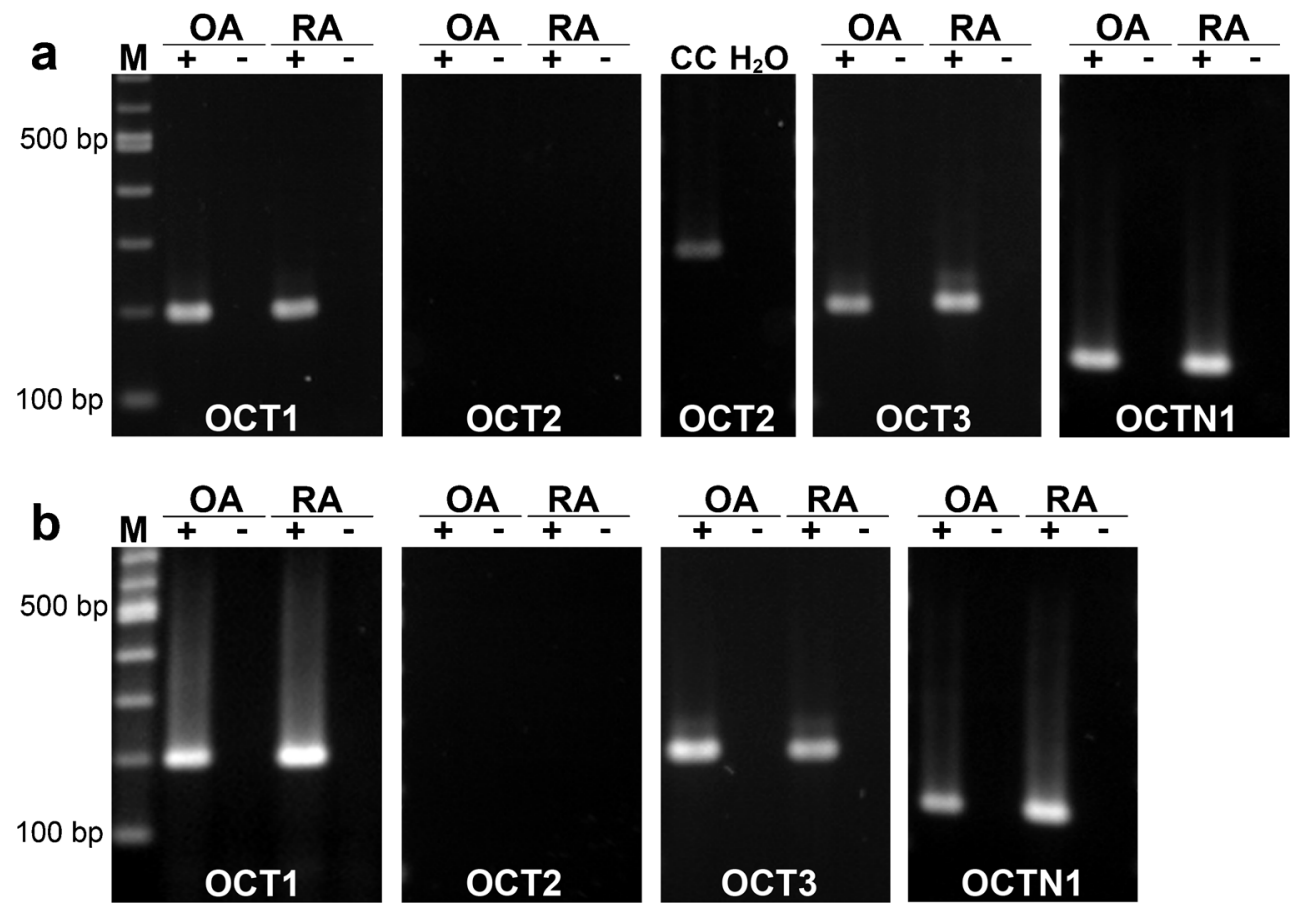
RNA isolation and qualitative reverse transcription plus the polymerase chain reaction (RT-PCR)

Total RNA was extracted from the samples by using the RNA Lipid Tissue Mini Kit (Qiagen, Hilden, Germany). Removal of genomic DNA contamination and subsequent reverse transcription was performed with the Quantitect Kit (Qiagen) according to the manufacture's protocol. Reactions without addition of reverse transcriptase were performed as controls (reverse transcription negative, RT-). AmpliTaq Gold polymerase (Applied Biosystems, Darmstadt, Germany) was used for cDNA amplification with gene-specific primers (Table 1; MWG, Ebersberg, Germany). For electrophoretic separation, RT-PCR products were subjected to $2 \%$ TRIS-acetate-EDTA agarose gel electrophoresis.

\section{Real-time RT-PCR}

Real-time RT-PCR analysis was performed by using genespecific primers (Table 1, MWG), SYBR Green PCR
Mastermix (Qiagen) and the I-Cycler IQ ${ }^{\mathrm{TM} 5}$ detection system (Bio-Rad, Munich, Germany). Standard and melt curves were performed to determine PCR efficiency and specificity of amplification, respectively. Mean cycle thresholds $(\mathrm{Ct})$ values were normalized to the reference gene $\beta 2$-microglobulin $(\beta \mathrm{MG})$. Neuroblastoma cell line SH-SY5Y or colon carcinoma cell line $\mathrm{CaCo}-2$ were used as positive controls.

Immunohistochemistry

Synovial tissue and cartilage samples were fixed in $4 \%$ phosphate-buffered paraformaldehyde (Merck, Darmstadt, Germany). Before being embedded in paraffin, cartilage samples were demineralized in 0.281 M TRIS-buffer containing $10 \%$ ethylene diamine tetra acetic acid (Merck). Sections of $3 \mu \mathrm{m}$ in thickness were cut and deparaffinized in a decreasing series of alcohols. For heat-induced antigen retrieval, sections were subjected to pressure-cooking in citric buffer $(\mathrm{pH} \mathrm{6.0)}$ for $15 \mathrm{~min}$. After the blocking of endogenous peroxidase with $\mathrm{H}_{2} \mathrm{O}_{2}$, sections were incubated with $1 \%$ bovine serum
Fig. 3 Expression of choline transporter-like (CTL) protein mRNA in the human joint. a, b RT-PCR for CTL1-CTL5 mRNA in synovia (a) and cartilage (b) from the hip of OA and RA patients (lanes $M 100$ bp ladder, lanes + RT+, lanes - RT-). c, d Real-time RT-PCR for CTL1CTL5 mRNA in hip samples of synovia (c) and cartilage (d) of OA and RA patients ( $n=5$ each). Data were normalized to reference gene $\beta \mathrm{MG}$ and are presented as box plots with the median being indicated by a solid line within the box
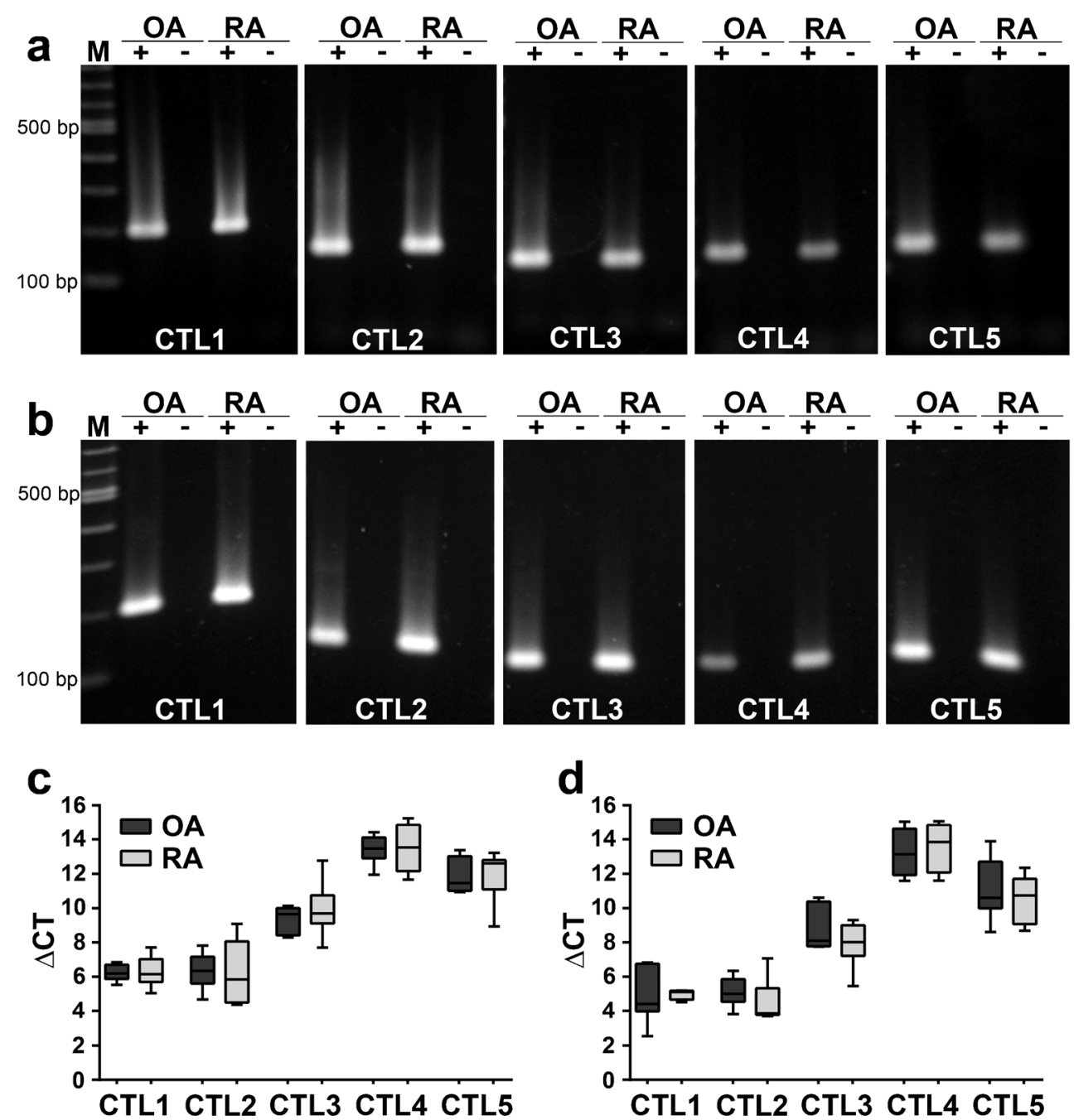
albumin (BSA; Sigma Aldrich, Taufkirchen, Germany) and $10 \%$ human serum (Sigma Aldrich) in phosphate-buffered saline (PBS) for $30 \mathrm{~min}$ at room temperature.

\section{Single-stain immunohistochemistry}

Slides were incubated with the indicated primary antibody (Table 2) in antibody diluent (Dako, Hamburg, Germany) and $10 \%$ human serum (Sigma Aldrich) overnight at $4{ }^{\circ} \mathrm{C}$. Sections were subjected to biotinylated rabbit anti-mouse (1:150) or biotinylated goat anti-rabbit (1:800) secondary antibody (both from Dako) diluted in PBS containing $1 \%$ BSA and $5 \%$ human serum for $30 \mathrm{~min}$ at room temperature. After further treatment with Vectastain ABC Elite Kit (Vector Laboratories, Burlingame, Calif., USA) according to the manufacturer's instructions, staining was visualized by using Nova Red (Vector Laboratories). Counterstaining was performed with hematoxylin and DePex (Serva, Heidelberg, Germany) was used for cover-slipping. Negative controls were performed without incubation of the primary antibodies and by using specific peptides (Table 2) for preabsorption overnight at $4{ }^{\circ} \mathrm{C}$. To test the specificity of the antibodies further, Western blot analysis was performed (see Electronic Supplementary Material). Sections were evaluated with a photomicroscope (Axiophot-2, Zeiss, Jena, Germany) equipped with a digital camera (DC500, Leica, Bensheim, Germany).
Double-stain immunohistochemistry with two mouse monoclonal primary antibodies

Primary antibodies were diluted in PBS containing $1 \%$ BSA and $10 \%$ human serum and incubated with the sections overnight at $4{ }^{\circ} \mathrm{C}$. For detection of the first primary antibody (Table 3), sections were incubated with rabbit anti-mouse IgG (1:25; Dako) followed by monoclonal mouse alkaline phosphatase/anti-alkaline phosphatase (APAAP; 1:25; Dako) for $30 \mathrm{~min}$ at room temperature each. Bound alkaline phosphatase was visualized by using Fast Blue chromogen (Sigma Aldrich). Antibodies were detached from the tissue by using another step of pressure-cooking. Sections were treated again for 30 min with $1 \%$ BSA in PBS followed by overnight incubation at $4{ }^{\circ} \mathrm{C}$ with the indicated second primary antibody (Table 3). After incubation with peroxidase-labeled rabbit anti-mouse antibody (1:70; Dako), staining was visualized by using 3,3' diaminobenzidine (DAB, Sigma Aldrich). Sections were cover-slipped with Kaiser's glycerol gelatine (Merck, Darmstadt, Germany). For control of staining, both primary antibodies were omitted or each primary antibody was omitted separately.

Double-stain immunohistochemistry with mouse and rabbit primary antibodies

A mixture of mouse and rabbit primary antibodies (Table 4) was diluted in antibody diluent (Dako) and incubated with the
Fig. 4 Immunohistochemical localization of CTL1 and CTL2 in the human joint. $\mathbf{a}, \mathbf{b}$ Immunohistochemical staining for CTL1 in synovial tissue of the hip joint of OA (a) and RA (b) patients. Insert in a Preabsorption control with specific CTL1 peptide. $\mathbf{c}, \mathbf{d}$

Immunohistochemical staining for CTL2 in synovial tissue of the hip joint of OA (c) and RA (d) patients. Insert in $\mathbf{c}$ Preabsorption control with specific CTL2 peptide
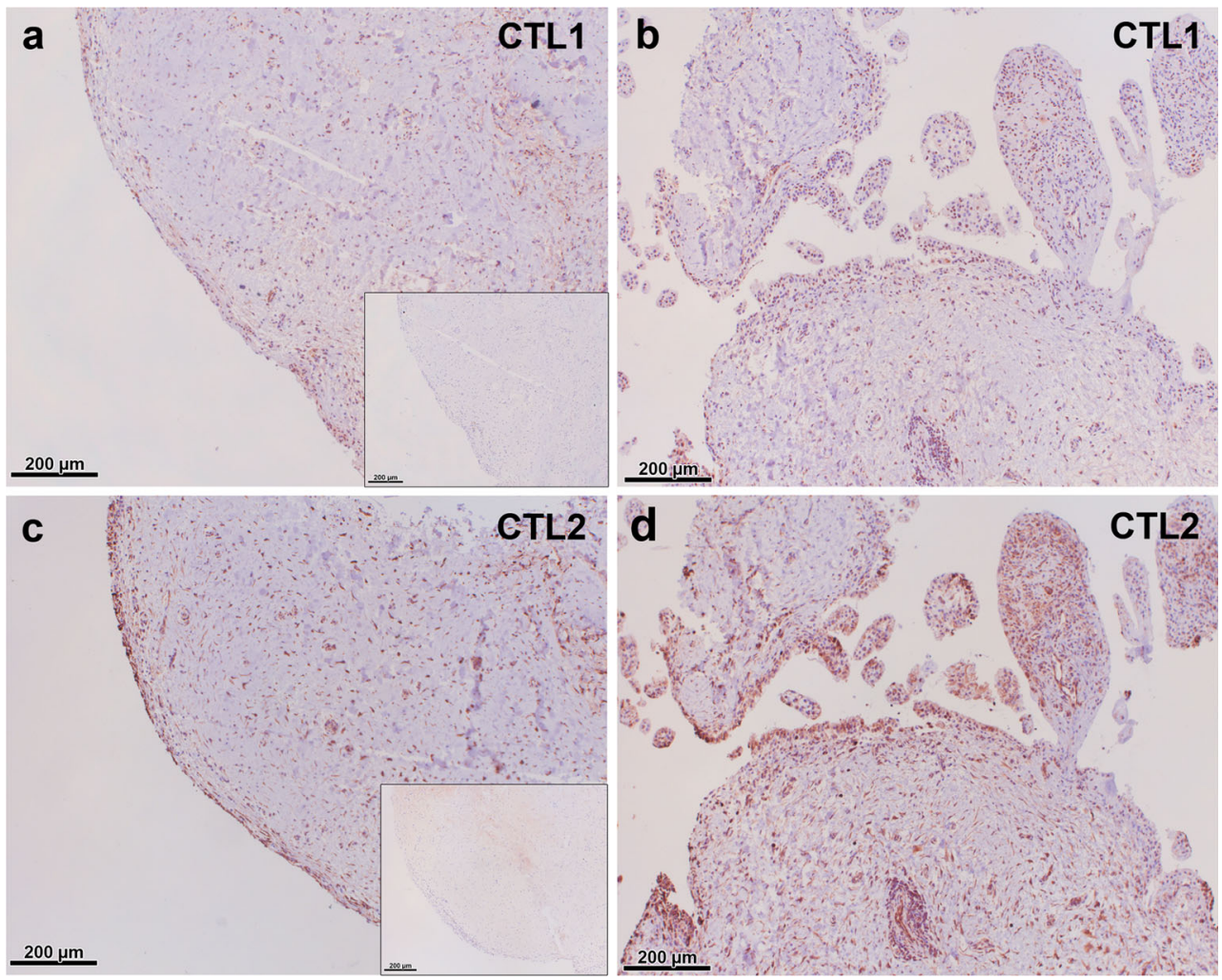
Fig. 5 CTL1 is expressed in macrophage-like and fibroblastlike synoviocytes. a, b Doublestaining for macrophage marker CD68 (blue) and CTL1 (brown) in synovial tissue. The boxed area in a indicates the region shown at higher magnification in $\mathbf{b}$. $\mathbf{c}, \mathbf{d}$ Double-staining for macrophage marker CD163 (blue) and CTL1 (brown) in synovial tissue. The boxed area in $\mathbf{c}$ indicates the region shown at higher magnification in $\mathbf{d}$. e, $\mathbf{f}$ Double-staining for prolyl-4-hydroxylase- $\beta$ ( $P 4 H$, blue) and CTL1 (brown) in synovial tissue. The boxed area in $\mathbf{e}$ indicates the region shown at higher magnification in $\mathbf{f}$

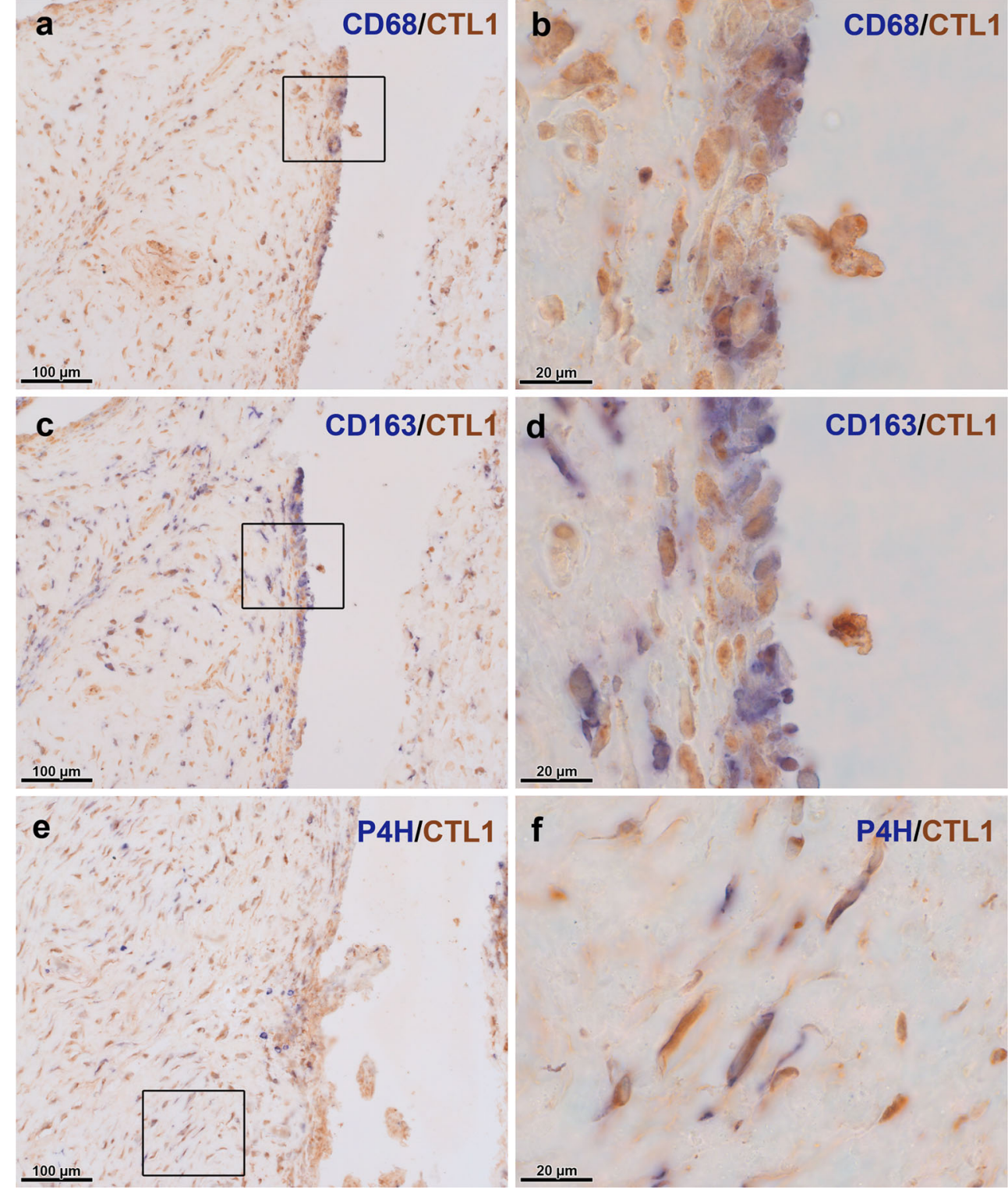

sections overnight at $4{ }^{\circ} \mathrm{C}$. After a 1-h treatment with alkalinephosphatase-labeled swine anti-rabbit antibody (1:30; Dako), staining was visualized with Fast Blue chromogen. Subsequently, sections were incubated with biotinylated rabbit anti-mouse secondary antibody (1:150; Dako) and staining was visualized by using Vectastain $\mathrm{ABC}$ Elite Kit and DAB. Kaiser's glycerol gelatine was used for cover-slipping. For control of staining, both antibodies were omitted or each primary antibody was omitted separately.

\section{Statistical analysis}

SPSS software (SPSS Institute, Chicago, Ill., USA) was used for statistical analysis. Delta Ct values were compared by the global non-parametric rank-sum Kruskal-Wallis test. If significant $(P \leq 0.05)$, the Mann-Whitney test was used for further analysis of statistical relevance.

\section{Results}

Classical neuronal components: CHT1 and VAChT

The classical neuronal choline transporter $\mathrm{CHT} 1$ was present in the synovial tissue of patients with OA and RA (Fig. 1a). In the joint cartilage, however, no CHT1 mRNA expression was detectable in OA or RA patients (Fig. 1b). The mediator of ACh storage in vesicles, VAChT, was neither expressed in synovial tissue nor in cartilage samples of the human joint, irrespective of pathology (Fig. 1a, b). PCR was controlled by using neuroblastoma cell line SH-SY5Y as a VAChTexpressing positive control (Fig. 1b). For every used sample, PCR for $\beta M G$ was performed to control RNA isolation and cDNA synthesis; an example is shown in Fig. 1c for synovial tissue and cartilage samples from patients with $\mathrm{OA}$ and RA. 


\section{OCTs and OCTN1}

In our previous study, we were able to show that $O C T 1$ and OCT3 were expressed in the synovial tissue of the knee joint without showing a significant difference in expression levels between samples from RA and OA patients (Schubert et al. 2012). In the synovia of the hip joint, we could detect both transporters in samples from RA and from OA patients (Fig. 2a). OCT1 and OCT3 mRNA were also both present in all analyzed cartilage samples of the joints (Fig. 2b), irrespective of OA or RA pathology. Moreover, for the transporter OCTN1, mRNA expression was observed in synovial tissue (Fig. 2a) and cartilage (Fig. 2b) from all patients. OCT2 mRNA, on the other hand, was detectable neither in synovial tissue (Fig. 2a) nor in cartilage (Fig. 2b) of any investigated sample.

\section{CTL proteins}

All five family members of the CTL proteins were present in synovial tissue (Fig. 3a) and cartilage (Fig. 3b) of the human joint. No difference in mRNA expression levels of any CTL family member was observed between OA and RA patients by real-time RT-PCR (Fig. 3c-d). In all analyzed samples, CTL1 and CTL2 mRNA were the most prominently expressed, followed by CTL3 and by a lower expression of CTL4 and CTL5 mRNA.
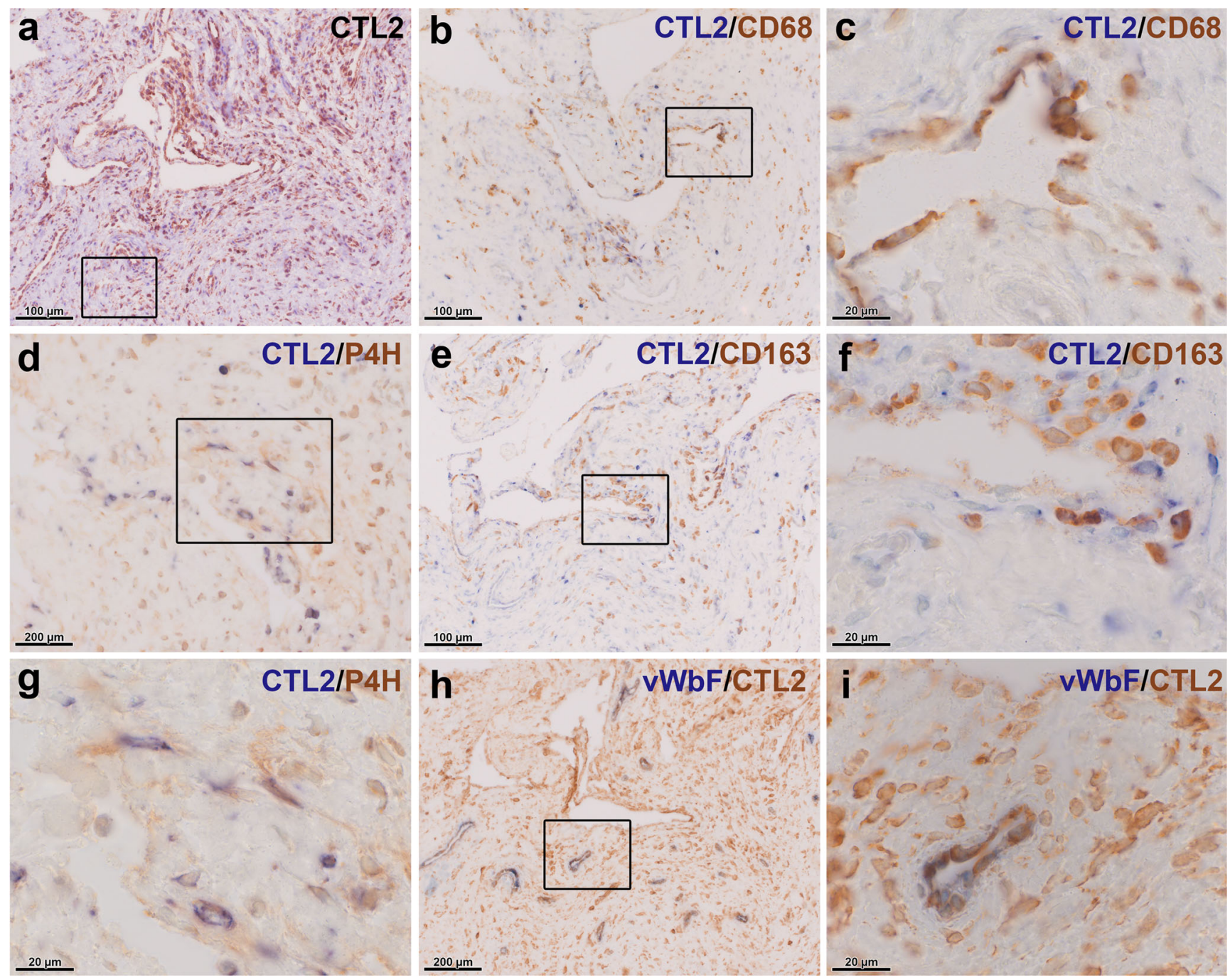

Fig. 6 CTL2 is expressed by synovial macrophages and fibroblasts and by endothelial cells. a Single-staining for CTL2 in synovial tissue. The boxed area indicates the area of staining that is represented in $\mathbf{d}$. $\mathbf{b}, \mathbf{c}$ Double-staining for CTL2 (blue) and macrophage marker CD68 (brown) in synovial tissue. The boxed area in $\mathbf{b}$ indicates the region shown at higher magnification in c. e, f Double-staining for CTL2 (blue) and macrophage marker CD163 (brown) in synovial tissue. The boxed area in $\mathbf{e}$ indicates the region shown at higher magnification in $\mathbf{f} . \mathbf{d}, \mathbf{g}$ Doublestaining for CTL2 (blue) and fibroblast marker, prolyl-4-hydroxylase- $\beta$ $(P 4 H$, brown), in synovial tissue. The boxed area in $\mathbf{d}$ indicates the region shown at higher magnification in $\mathbf{g}$. h, i Double-staining for CTL2 and endothelial cell marker, von Willebrand factor $(v W b F)$. The boxed area in $\mathbf{h}$ indicates the region shown at higher magnification in $\mathbf{i}$ 
Little is known about the expression of CTL proteins in the joint. Thus, we were further interested in the protein localization of these choline transporters and performed immunohistochemical staining for the two most prominently expressed members, namely CTL1 and CTL2, in synovial tissue (Fig. 4). CTL1 and CTL2 protein were shown to be present in the synovial tissue of OA (Fig. 4a, c) and RA (Fig. 4b, d) patients and staining was mainly observed in the synovial lining layer but also in the subintimal layer. Double-staining of CTL1 with macrophage markers CD68 and CD163 and with fibroblast marker prolyl-4-hydroxylase- $\beta$ localized the expression of this transporter to macrophage-like (Fig. 5a-d) and fibroblast-like (Fig. 5e, f) cells. Furthermore, the CTL2 protein was detected in synovial macrophages (Fig. 6b, c, e, f) and fibroblasts (Fig. 6d, g). Expression of CTL2 was further determined in endothelial cells by using double-staining for the von Willebrand factor (Fig. 6h, i). Moreover, the ACh- synthesizing enzyme CarAT was also detectable in CTL1positive (Fig. 7b, c) and CTL2-positive (Fig. 7e, f) cells and the staining pattern of these two CTL proteins (Fig. 7a, d) was similar to that observed for CHT1 (Fig. 7g), OCT1 (Fig. 7h) and OCT3 (Fig. 7i).

\section{Discussion}

In the present study, we were able to show that all necessary components for the transport of choline into the cell and for the release of $\mathrm{ACh}$ are present in the synovial tissue and cartilage of the human hip joint (Fig. 8). At the mRNA expression level, no differences between samples of OA or RA origin are measurable, indicating that the pathological state might not influence the transport of choline or ACh in the human joint.
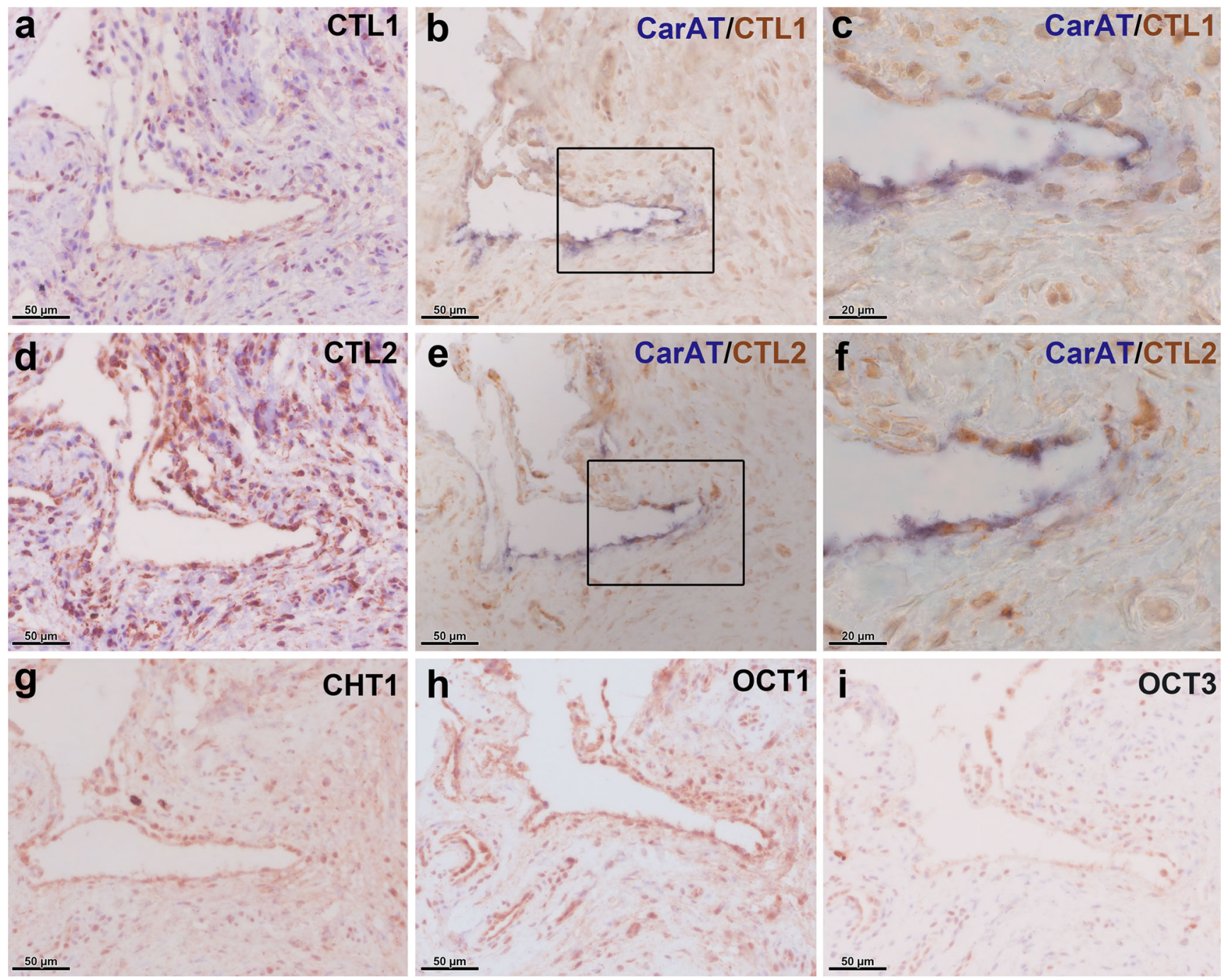

Fig. 7 CTL1- and CTL2-positive cells express the ACh-synthesizing enzyme, carnitin acetyltransferase (CarAT). a Single-staining for CTL1 in synovial tissue. b, c Double-staining for CarAT (blue) and CTL1 (brown) in synovial tissue. The boxed area in $\mathbf{b}$ indicates the region shown at

higher magnification in c. d Single-staining for CTL2 in synovial tissue. e, f Double-staining for CarAT (blue) and CTL2 (brown). The boxed area in $\mathbf{e}$ indicates the region shown at higher magnification in $\mathbf{f}$. g-i Singlestaining for CHT1 (g), OCT1 (h) and OCT3 (i) on synovial tissue 


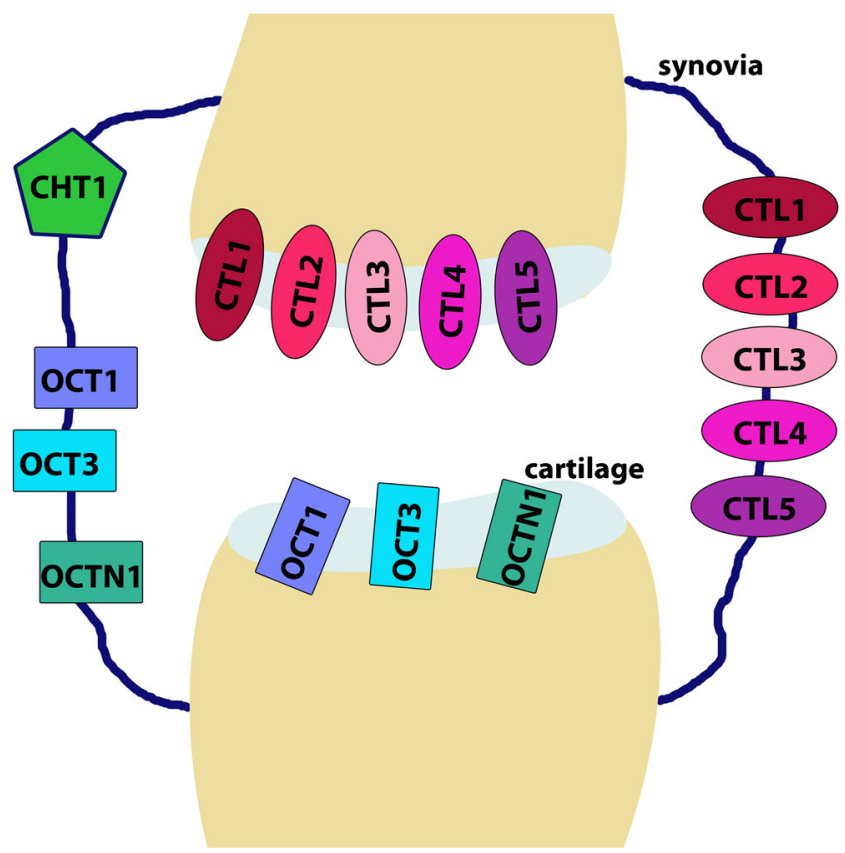

Fig. 8 Representation of the expression of choline and acetylcholine transporters in the human joint. The transporters CTL1-5, OCT1, OCT3, and OCTN1 are expressed in the synovia and the cartilage of the human joint. The classic neuronal choline transporter CHT1 is only expressed in synovial tissue, and not in the cartilage of the joint

This is the first time that all members of the recently described family of CTL proteins have been shown to be expressed in the synovial tissue and cartilage of the human joint. CTL1, the best characterized member of the CTL family, is expressed the most prominently in both synovia and cartilage. This is in accordance with other tissues and cells such as keratinocytes in which CTL1 expression has also been found to be more pronounced than that of other CTL proteins (Uchida et al. 2009). We have been able to localize CTL1 protein expression to macrophage-like and fibroblast-like cells of the synovial tissue. As the specificity of CD68 as a macrophage marker has been critically discussed, we additionally chose to use CD163 to label macrophage-like synoviocytes in the tissue (Fonseca et al. 2002; Kunisch et al. 2004; Lau et al. 2004). Our finding is consistent with previous studies that identified CTL1 as being a constitutively expressed cell surface antigen on monocytic cells (Wille et al. 2001). Regulation of CTL1 in immune cells has only been reported for dendritic cells, as activation with calcium ionophores in these cells leads to the down-regulation of CTL1 (Wille et al. 2001). Further, human CTL1 has been shown to be up-regulated in several cancer cell lines (Wang et al. 2007) in myopathies and leukemias (Yuan et al. 2006). In the present study, however, no significant difference in CTL1 expression was observed between joints of OA and RA patients. For the human CTL1 gene, two splice variants have been characterized, encoding two proteins differing in a C-terminal peptide (Yuan et al.
2006). However, the specific roles and significance of the two CTL1 isoforms still have to be analyzed. Thus, in the present study, we used primers amplifying both transcript variants.

CTL2 was first discovered in the supporting cells of the inner ear (Zajic et al. 1991) and antibodies against CTL2 are reported to cause hair cell death and hearing loss (Nair et al. 2004). Notably, antibodies against CTL2 have been detected in $50 \%$ of patients with autoimmune hearing loss (Kommareddi et al. 2009) indicating a prominent role of CTL2 in this and possibly other autoimmune diseases. Interestingly, a single nucleotide polymorphism in the CTL2 gene has been reported to encode for the human neutrophil alloantigen (HNA)-3a, which represents the target antigen for antibody-mediated transfusion-related acute lung injury (Curtis et al. 2010; Greinacher et al. 2010). In the human hip joint, we were able to localize CTL2 in macrophage-like and fibroblast-like cells and in endothelial cells of the synovial tissue. The latter finding is in accordance with previous studies in which CTL2 expression has been found in monocytes and endothelial cells (Flesch et al. 2013). No expression differences between joints of OA and RA patients have been observed. As for CTL1, alternative splicing results in two isoforms of the CTL2 protein differing in the first 12 amino acids of presumably the cytoplasmic N-terminus (Nair et al. 2004) and in one isoform that differs in its C-terminus and that might be epithelial-cell-specific (Kommareddi et al. 2010). To date, whether the various isoforms can exert diverse functions is unclear and thus, in the present study, we first took a general look at CTL2 expression by choosing primers amplifying all isoforms.

We were able to show that the other family members, namely CTL3, CTL4 and CTL5, are also expressed, though to a lesser extent, in synovial tissue and cartilage of the human joint. However, little is known about the functionality of these three transporters (Inazu 2014). Interestingly, CTL4 mRNA expression, which has been shown to be related to the synthesis and release of non-neuronal ACh in cancer cells (Song et al. 2013), is detectable in all analyzed samples, indicating a possible role of this transporter for ACh release also in the human joint.

From the family of polyspecific OCTs, both OCT1 and OCT3 mRNA are expressed in cartilage and in synovia of the human joint, whereas $O C T 2$ is not detectable in any analyzed sample. This observation is consistent with other studies reporting that OCT1 and OCT3 show a rather broad tissue expression pattern, whereas the distribution of OCT2 seems to be more restricted (Inazu 2014; Koepsell et al. 2007). The transporter OCTN1 has been shown to be expressed in a variety of tissues, especially immune-related tissue, such as 
spleen and bone marrow and in several immune cell types (Koepsell et al. 2007; Tokuhiro et al. 2003). Tokuhiro et al. (2003) reported that OCTN1 is expressed in synovial tissue of RA patients and in arthritic mice, whereas OCTN1 expression has not been observed non-arthritic control mice. Further, the induction of OCTN1 mRNA expression has been observed in human synovial fibroblasts isolated from RA patients after stimulation with tumornecrosis factor-alpha (Tokuhiro et al. 2003). We were able to confirm the expression of OCTN1 in the synovial tissue of the hip joint of RA patients; however, in OA patients serving as the non-inflammatory control, the expression of OCTN1 is also detectable. The same can be observed for the analyzed cartilage samples in our study. Most interestingly, an association between functional variants of the OCTN1 gene and RA has been reported in the Japanese population leading to the hypothesis that the small nuclear polymorphism (SNP) in intron 1 of the OCTN1 gene lowers the affinity for the Runt-related transcription factor 1 (RUNX1), which regulates OCTN1 expression (Tokuhiro et al. 2003). However, the identification of OCTN1 as an RA susceptibility gene could not be verified in the Canadian (Newman et al. 2005), UK (Barton et al. 2005), or Spanish (Martinez et al. 2006; Orozco et al. 2006) population and could not be reproduced by another group working on the Japanese population (Kuwahara et al. 2005).

Taken together, these data suggest that the import of choline for ACh synthesis is facilitated mainly by OCT1 and members of the CTL family in the synovial tissue and cartilage of the human joint. In synovial tissue but not cartilage, the classic neuronal component CHT1 might also contribute to this process. The transport of ACh out of synovial or cartilage cells occurs directly and not via vesicles, as no VAChT expression is detectable. Members of the OCT family and CTL4 and OCTN1 might be responsible for mediating this direct release of ACh. In the synovial tissue, the transporters CTL1 and CTL2 have been localized to macrophagelike and fibroblast-like cells and other transporters show a similar expression pattern in this tissue. The presence of the ACh-synthesizing enzyme CarAT in cells expressing CTL1 and CTL2 provides a hint that these nonneuronal synovial cells produce ACh. Thus, all important components for the synthesis and release of $\mathrm{ACh}$ are present in the synovial tissue and cartilage of the human joint but no differences between $\mathrm{OA}$ and RA pathology are detectable.

Acknowledgments The authors are grateful to Prof. Ludwig Bause (Abteilung für Rheumaorthopädie, St. Josef-Stift Sendenhorst, Sendenhorst, Germany), Prof. Thomas Härer (Orthopädie Bad Hersfeld, Bad Hersfeld) and Prof. Bernd Jung (Orthopädische Klinik Braunfels,
Braunfels, Germany) for providing tissues of OA and RA patients and to Olga Dakischew and Gabriele Fuchs-Moll for excellent technical assistance.

Open Access This article is distributed under the terms of the Creative Commons Attribution License, which permits any use, distribution and reproduction in any medium, provided the original author(s) and the source are credited.

\section{References}

Altman R, Asch E, Bloch D, Bole G, Borenstein D, Brandt K, Christy W, Cooke TD, Greenwald R, Hochberg M, Howell D, Kaplan D, Koopman W, Longley SIII, Mankin H, McShane DJ, Medsger T Jr, Meenan R, Mikkelsen W, Mqskowitz R, Murphy W, Rothschild B, Segal M, Sokoloff L, Wolfe F (1986) Development of criteria for the classification and reporting of osteoarthritis. Classification of osteoarthritis of the knee. Diagnostic and Therapeutic Criteria Committee of the American Rheumatism Association. Arthritis Rheum 29:1039-1049

Arnett FC, Edworthy SM, Bloch DA, McShane DJ, Fries JF, Cooper NS, Healey LA, Kaplan SR, Liang MH, Luthra HS, Medsger TA Jr, Mitchell DM, Neustadt DH, Pinals RS, Schaller JG, Sharp JT, Wilder RL, Hunder GG (1988) The American Rheumatism Association 1987 revised criteria for the classification of rheumatoid arthritis. Arthritis Rheum 31:315-324

Barton A, Eyre S, Bowes J, Ho P, John S, Worthington J (2005) Investigation of the SLC22A4 gene (associated with rheumatoid arthritis in a Japanese population) in a United Kingdom population of rheumatoid arthritis patients. Arthritis Rheum 52:752-758

Beckmann J, Lips KS (2013) The non-neuronal cholinergic system in health and disease. Pharmacology 92:286-302

Busch AE, Quester S, Ulzheimer JC, Waldegger S, Gorboulev V, Arndt P, Lang F, Koepsell H (1996) Electrogenic properties and substrate specificity of the polyspecific rat cation transporter rOCT1. J Biol Chem 271:32599-32604

Curtis BR, Cox NJ, Sullivan MJ, Konkashbaev A, Bowens K, Hansen K, Aster RH (2010) The neutrophil alloantigen HNA-3a (5b) is located on choline transporter-like protein 2 and appears to be encoded by an $\mathrm{R} \rightarrow \mathrm{Q} 154$ amino acid substitution. Blood 115:2073-2076

Eraly SA, Monte JC, Nigam SK (2004) Novel slc22 transporter homologs in fly, worm, and human clarify the phylogeny of organic anion and cation transporters. Physiol Genomics 18:12-24

Erickson JD, Varoqui H, Schafer MK, Modi W, Diebler MF, Weihe E, Rand J, Eiden LE, Bonner TI, Usdin TB (1994) Functional identification of a vesicular acetylcholine transporter and its expression from a "cholinergic" gene locus. J Biol Chem 269: 21929-21932

Ferguson SM, Bazalakova M, Savchenko V, Tapia JC, Wright J, Blakely $\mathrm{RD}$ (2004) Lethal impairment of cholinergic neurotransmission in hemicholinium-3-sensitive choline transporter knockout mice. Proc Natl Acad Sci U S A 101:8762-8767

Flesch BK, Wesche J, Berthold T, Goldmann T, Hundt M, Greinacher A, Bux J (2013) Expression of the CTL2 transcript variants in human peripheral blood cells and human tissues. Transfusion 53:32173223

Fonseca JE, Edwards JC, Blades S, Goulding NJ (2002) Macrophage subpopulations in rheumatoid synovium: reduced CD163 expression in $\mathrm{CD} 4+\mathrm{T}$ lymphocyte-rich microenvironments. Arthritis Rheum 46:1210-1216 
Fujii T, Takada-Takatori Y, Horiguchi K, Kawashima K (2012) Mediatophore regulates acetylcholine release from $\mathrm{T}$ cells. J Neuroimmunol 244:16-22

Greinacher A, Wesche J, Hammer E, Furll B, Volker U, Reil A, Bux J (2010) Characterization of the human neutrophil alloantigen-3a. Nat Med 16:45-48

Grimsholm O, Rantapaa-Dahlqvist S, Dalen T, Forsgren S (2008) Unexpected finding of a marked non-neuronal cholinergic system in human knee joint synovial tissue. Neurosci Lett 442:128-133

Inazu M (2014) Choline transporter-like proteins CTLs/SLC44 family as a novel molecular target for cancer therapy. Biopharm Drug Dispos (in press)

Israel M, Dunant Y (1998) Acetylcholine release. Reconstitution of the elementary quantal mechanism. J Physiol (Paris) 92:123-128

Kirkpatrick CJ, Bittinger F, Unger RE, Kriegsmann J, Kilbinger H, Wessler I (2001) The non-neuronal cholinergic system in the endothelium: evidence and possible pathobiological significance. Jpn J Pharmacol 85:24-28

Koepsell H (2004) Polyspecific organic cation transporters: their functions and interactions with drugs. Trends Pharmacol Sci 25:375-381

Koepsell H, Lips K, Volk C (2007) Polyspecific organic cation transporters: structure, function, physiological roles, and biopharmaceutical implications. Pharm Res 24:1227-1251

Kommareddi PK, Nair TS, Vallurupalli M, Telian SA, Arts HA, ElKashlan HK, Sataloff RT, Carey TE (2009) Autoantibodies to recombinant human CTL2 in autoimmune hearing loss. Laryngoscope 119:924-932

Kommareddi PK, Nair TS, Thang LV, Galano MM, Babu E, Ganapathy V, Kanazawa T, McHugh JB, Carey TE (2010) Isoforms, expression, glycosylation, and tissue distribution of CTL2/SLC44A2. Protein J 29:417-426

Kunisch E, Fuhrmann R, Roth A, Winter R, Lungershausen W, Kinne RW (2004) Macrophage specificity of three anti-CD68 monoclonal antibodies (KP1, EBM11, and PGM1) widely used for immunohistochemistry and flow cytometry. Ann Rheum Dis 63:774-784

Kuwahara M, Ikari K, Momohara S, Nakamura T, Hara M, Yamanaka H, Tomatsu T, Kamatani N (2005) Failure to confirm association between SLC22A4 polymorphism and rheumatoid arthritis in a Japanese population. Arthritis Rheum 52:2947-2948

Lau SK, Chu PG, Weiss LM (2004) CD163: a specific marker of macrophages in paraffin-embedded tissue samples. Am J Clin Pathol 122:794-801

Lindblad SS, Mydel P, Jonsson IM, Senior RM, Tarkowski A, Bokarewa M (2009) Smoking and nicotine exposure delay development of collagen-induced arthritis in mice. Arthritis Res Ther 11:R88

Lips KS, Pfeil U, Haberberger RV, Kummer W (2002) Localisation of the high-affinity choline transporter-1 in the rat skeletal motor unit. Cell Tissue Res 307:275-280

Lips KS, Pfeil U, Reiners K, Rimasch C, Kuchelmeister K, BraunDullaeus RC, Haberberger RV, Schmidt R, Kummer W (2003) Expression of the high-affinity choline transporter $\mathrm{CHT} 1$ in rat and human arteries. J Histochem Cytochem 51:1645-1654

Lips KS, Volk C, Schmitt BM, Pfeil U, Arndt P, Miska D, Ermert L, Kummer W, Koepsell H (2005) Polyspecific cation transporters mediate luminal release of acetylcholine from bronchial epithelium. Am J Respir Cell Mol Biol 33:79-88

Lips KS, Wunsch J, Zarghooni S, Bschleipfer T, Schukowski K, Weidner W, Wessler I, Schwantes U, Koepsell H, Kummer W (2007) Acetylcholine and molecular components of its synthesis and release machinery in the urothelium. Eur Urol 51:1042-1053

Machova E, O'Regan S, Newcombe J, Meunier FM, Prentice J, Dove R, Lisa V, Dolezal V (2009) Detection of choline transporter-like 1 protein CTL1 in neuroblastoma $\times$ glioma cells and in the CNS, and its role in choline uptake. J Neurochem 110:1297-1309

Martinez A, Valdivia A, Pascual-Salcedo D, Balsa A, FernandezGutierrez B, De la Concha E, Urcelay E (2006) Role of
SLC22A4, SLC22A5, and RUNX1 genes in rheumatoid arthritis. J Rheumatol 33:842-846

Michel V, Bakovic M (2009) The solute carrier 44A1 is a mitochondrial protein and mediates choline transport. FASEB J 23:2749-2758

Michel V, Bakovic M (2012) The ubiquitous choline transporter SLC44A1. Cent Nerv Syst Agents Med Chem 12:70-81

Nair TS, Kozma KE, Hoefling NL, Kommareddi PK, Ueda Y, Gong TW, Lomax MI, Lansford CD, Telian SA, Satar B, Arts HA, El-Kashlan HK, Berryhill WE, Raphael Y, Carey TE (2004) Identification and characterization of choline transporter-like protein 2 , an inner ear glycoprotein of 68 and $72 \mathrm{kDa}$ that is the target of antibody-induced hearing loss. J Neurosci 24:1772-1779

Nakamura T, Fujiwara R, Ishiguro N, Oyabu M, Nakanishi T, Shirasaka Y, Maeda T, Tamai I (2010) Involvement of choline transporter-like proteins, CTL1 and CTL2, in glucocorticoid-induced acceleration of phosphatidylcholine synthesis via increased choline uptake. Biol Pharm Bull 33:691-696

Newman B, Wintle RF, van Oene M, Yazdanpanah M, Owen J, Johnson B, Gu X, Amos CI, Keystone E, Rubin LA, Siminovitch KA (2005) SLC22A4 polymorphisms implicated in rheumatoid arthritis and Crohn's disease are not associated with rheumatoid arthritis in a Canadian Caucasian population. Arthritis Rheum 52:425-429

O'Regan S, Traiffort E, Ruat M, Cha N, Compaore D, Meunier FM (2000) An electric lobe suppressor for a yeast choline transport mutation belongs to a new family of transporter-like proteins. Proc Natl Acad Sci U S A 97:1835-1840

Orozco G, Sanchez E, Gonzalez-Gay MA, Lopez-Nevot MA, Torres B, Pascual-Salcedo D, Balsa A, Pablos JL, Garcia A, GonzalezEscribano MF, Martin J (2006) SLC22A4, RUNX1, and SUMO4 polymorphisms are not associated with rheumatoid arthritis: a casecontrol study in a Spanish population. J Rheumatol 33:1235-1239

Pan XH, Zhang J, Yu X, Qin L, Kang L, Zhang P (2010) New therapeutic approaches for the treatment of rheumatoid arthritis may rise from the cholinergic anti-inflammatory pathway and antinociceptive pathway. ScientificWorldJournal 10:2248-2253

Pfeil U, Haberberger RV, Lips KS, Eberling L, Grau V, Kummer W (2003) Expression of the high-affinity choline transporter CHT1 in epithelia. Life Sci 72:2087-2090

Pochini L, Scalise M, Galluccio M, Pani G, Siminovitch KA, Indiveri C (2012) The human OCTN1 (SLC22A4) reconstituted in liposomes catalyzes acetylcholine transport which is defective in the mutant L503F associated to the Crohn's disease. Biochim Biophys Acta 1818:559-565

Rana OR, Schauerte P, Kluttig R, Schroder JW, Koenen RR, Weber C, Nolte KW, Weis J, Hoffmann R, Marx N, Saygili E (2010) Acetylcholine as an age-dependent non-neuronal source in the heart. Auton Neurosci 156:82-89

Rodriguez-Diaz R, Dando R, Jacques-Silva MC, Fachado A, Molina J, Abdulreda MH, Ricordi C, Roper SD, Berggren PO, Caicedo A (2011) Alpha cells secrete acetylcholine as a non-neuronal paracrine signal priming beta cell function in humans. Nat Med 17:888-892

Schubert J, Beckmann J, Hartmann S, Morhenn HG, Szalay G, Heiss C, Schnettler R, Lips KS (2012) Expression of the non-neuronal cholinergic system in human knee synovial tissue from patients with rheumatoid arthritis and osteoarthritis. Life Sci 91:1048-1052

Song P, Rekow SS, Singleton CA, Sekhon HS, Dissen GA, Zhou M, Campling B, Lindstrom J, Spindel ER (2013) Choline transporterlike protein 4 (CTL4) links to non-neuronal acetylcholine synthesis. J Neurochem 126:451-461

Sweet DH, Miller DS, Pritchard JB (2001) Ventricular choline transport: a role for organic cation transporter 2 expressed in choroid plexus. $\mathrm{J}$ Biol Chem 276:41611-41619

Tokuhiro S, Yamada R, Chang X, Suzuki A, Kochi Y, Sawada T, Suzuki M, Nagasaki M, Ohtsuki M, Ono M, Furukawa H, Nagashima M, Yoshino S, Mabuchi A, Sekine A, Saito S, Takahashi A, Tsunoda T, Nakamura Y, Yamamoto K (2003) An intronic SNP in a RUNX1 
binding site of SLC22A4, encoding an organic cation transporter, is associated with rheumatoid arthritis. Nat Genet 35:341-348

Tracey KJ (2009) Reflex control of immunity. Nat Rev Immunol 9:418-428

Traiffort E, Ruat M, O'Regan S, Meunier FM (2005) Molecular characterization of the family of choline transporter-like proteins and their splice variants. J Neurochem 92:1116-1125

Traiffort E, O'Regan S, Ruat M (2013) The choline transporter-like family SLC44: properties and roles in human diseases. Mol Aspects Med 34:646-654

Tucek S (1982) The synthesis of acetylcholine in skeletal muscles of the rat. J Physiol (Lond) 322:53-69

Uchida Y, Inazu M, Takeda H, Yamada T, Tajima H, Matsumiya T (2009) Expression and functional characterization of choline transporter in human keratinocytes. J Pharmacol Sci 109:102-109

van Maanen MA, Lebre MC, van der Poll T, LaRosa GJ, Elbaum D, Vervoordeldonk MJ, Tak PP (2009) Stimulation of nicotinic acetylcholine receptors attenuates collagen-induced arthritis in mice. Arthritis Rheum 60:114-122

van Maanen MA, Stoof SP, Larosa GJ, Vervoordeldonk MJ, Tak PP (2010) Role of the cholinergic nervous system in rheumatoid arthritis: aggravation of arthritis in nicotinic acetylcholine receptor alpha7 subunit gene knockout mice. Ann Rheum Dis 69:1717-1723

Wang T, Li J, Chen F, Zhao Y, He X, Wan D, Gu J (2007) Choline transporters in human lung adenocarcinoma: expression and functional implications. Acta Biochim Biophys Sin 39:668-674

Wessler I, Roth E, Deutsch C, Brockerhoff P, Bittinger F, Kirkpatrick CJ, Kilbinger H (2001) Release of non-neuronal acetylcholine from the isolated human placenta is mediated by organic cation transporters. Br J Pharmacol 134:951-956
Wessler I, Kilbinger H, Bittinger F, Unger R, Kirkpatrick CJ (2003) The non-neuronal cholinergic system in humans: expression, function and pathophysiology. Life Sci 72:2055-2061

Westman M, Saha S, Morshed M, Lampa J (2010) Lack of acetylcholine nicotine alpha 7 receptor suppresses development of collagen-induced arthritis and adaptive immunity. Clin Exp Immunol 162:62-67

Wille S, Szekeres A, Majdic O, Prager E, Staffler G, Stock1 J, Kunthalert D, Prieschl EE, Baumruker T, Burtscher H, Zlabinger GJ, Knapp W, Stockinger H (2001) Characterization of CDw92 as a member of the choline transporter-like protein family regulated specifically on dendritic cells. J Immunol 167:5795-5804

Yabuki M, Inazu M, Yamada T, Tajima H, Matsumiya T (2009) Molecular and functional characterization of choline transporter in rat renal tubule epithelial NRK-52E cells. Arch Biochem Biophys 485:88-96

Yamada T, Inazu M, Tajima H, Matsumiya T (2011) Functional expression of choline transporter-like protein 1 (CTL1) in human neuroblastoma cells and its link to acetylcholine synthesis. Neurochem Int 58:354-365

Yu H, Yang YH, Rajaiah R, Moudgil KD (2011) Nicotine-induced differential modulation of autoimmune arthritis in the Lewis rat involves changes in interleukin-17 and anti-cyclic citrullinated peptide antibodies. Arthritis Rheum 63:981-991

Yuan Z, Tie A, Tarnopolsky M, Bakovic M (2006) Genomic organization, promoter activity, and expression of the human choline transporter-like protein 1. Physiol Genomics 26:76-90

Zajic G, Nair TS, Ptok M, Van Waes C, Altschuler RA, Schacht J, Carey TE (1991) Monoclonal antibodies to inner ear antigens. I. Antigens expressed by supporting cells of the guinea pig cochlea. Hear Res 52:59-71 